Original Research Article

\title{
Preliminary phytochemical screening and GC-MS analysis of Cladophora glomerata: green marine algae
}

\author{
Usha N. S. ${ }^{1}$, Sabari Anand J. V. ${ }^{2 *}$, Mangaiyarkarasi ${ }^{3}$
}

${ }^{1}$ Department of Pharmacology, MVJMC and RH, Hosakote, Bangalore, Karnataka, India ${ }^{2}$ Department of Pharmacology, MGMCRI, Puducherry, India ${ }^{3}$ Senior Scientist, CIDRF, SBV University, Puducherry, India

Received: 29 January 2019

Revised: 06 March 2019

Accepted: 11 March 2019

\section{*Correspondence to:}

Dr. Sabari Anand JV, Email: Crony.8681@gmail.com

Copyright: (C) the author(s), publisher and licensee Medip Academy. This is an openaccess article distributed under the terms of the Creative Commons Attribution NonCommercial License, which permits unrestricted noncommercial use, distribution, and reproduction in any medium, provided the original work is properly cited.

\begin{abstract}
Background: Seaweeds since ages are excellent source of biologically active ingredients. Several Asian countries have a strong tradition of using various seaweeds in herbal medicines preparations. These plants contain various phytochemical constituents having biological activities. Seaweeds are the source of phytochemicals namely agar-agar, carrageenan and algin, which are extensively used in various industries such as food, confectionary, textiles, pharmaceuticals, dairy and paper industries mostly as gelling, stabilizing and thickening agents. They are also used for human consumption, animal feed and as manure in several countries. Several Asian countries are using various seaweeds in traditional medicines.

Methods: In the present study, the shade dried and methanolic extract of Cladophora glomerata, a marine green algae was subjected to preliminary phytochemical and gas chromatography-mass spectrometry analysis(GC-MS) to identify the various bioactive components.

Results: The methanolic extract of Cladophora glomerata revealed the presence of alkaloids, glycosides, flavonoids, saponins, diterpenes and carbohydrates. The GC-MS analysis of the methanolic extract of Cladophora glomerata showed the presence of 42 different compounds. The major compounds were dibutyl phthalate $(27.07 \%)$, hexadecanoic acid, methyl ester (9.58\%), 1,2-benzene-dicarboxylic acid $(8.11 \%)$, octatriacontyl trifluoroacetate $(6.81 \%)$, cholesterol $(6.66 \%)$.

Conclusions: Thus, in the present study of Cladophora glomerata, phytochemical and GC-MS analysis provides an important novel information to support further ongoing studies to evaluate structure of bioactive compound and its pharmacological activities.
\end{abstract}

Keywords: Cladophora glomerata, GC-MS, Phytochemical analysis, Seaweed

\section{INTRODUCTION}

Seaweeds or macroalgae form an important constituent of marine living organisms. About $90 \%$ of marine plants are algae, which is a primary source of food for aquatic organisms as well as source of human diet in several Asian countries. People in coastal areas consume fresh and dry seaweeds. ${ }^{1}$ Marine algae have served as a source of pharmacological active metabolites with various purpose. ${ }^{2}$ Algae are reservoir of various important phytoconstituents like flavonoids, phenolic compounds, saponins, steroids, tannins, carotenoids, pigments, enzymes, proteins. ${ }^{3}$ The active compound extracted from marine algae are used in traditional medicine. The use of active substances in curing diseases are said to have fewer side effects. ${ }^{4}$ Recent researches have shown that marine algae exhibit various biological activities. ${ }^{5-7}$ Phytochemical analysis of seaweeds lays the foundation for drug designing, drug development and drug production.

Cladophora glomerata is a filamentous green macro alga with typical branched thalli. ${ }^{8}$ Cladophora occurs both in 
marine and fresh water habitat. ${ }^{8}$ These species contain bioactives such as saturated and unsaturated fatty acids, sterols, typenoids and phenolic compounds. ${ }^{9-11}$ The present study was performed to analyse the different phytochemical constituents present in Cladophora glomerata along with GC-MS finger printing.

\section{METHODS}

\section{Collection of plant material}

The fresh sample of Cladophora glomerata seaweed was collected from Rameswaram costal area, Tamil Nadu, India and it was authenticated by Dr. Mangaiyarkarasi, Marine Biologist, CIDRF, SBV University, Puducherry, India. The sample was thoroughly washed with seawater to remove epiphytes followed by tap water to remove salts and other extraneous materials. The seaweed was washed with water, shade dried and powdered coarsely.

\section{Preparation of sample}

Crude extract was obtained after maceration with $95 \%$ methanol at room temperature for 72 hours and repeated till exhaustion of the material. Thereafter, the methanolic extract was distilled, evaporated and dried under reduced pressure to yield methanolic extract.

\section{Phytochemical analysis of Cladophora glomerata}

Methanolic extract of Cladophora glomerata (Green algae) powder was subjected to different qualitative chemical tests for establishing profiles of the extract for its chemical composition. ${ }^{12}$

\section{Phytochemical screening}

Qualitative phytochemical analysis of methanolic extract of Cladophora glomerata was performed based on the method of sofowara, Trease and Evans and Harborne. ${ }^{13}$

\section{Detection of alkaloids}

Methanolic extract of Cladophora glomerata was dissolved in enough of dilute hydrochloric acid and filtered.

- Mayer's test includes methanolic extract treated with Mayer's reagent (potassium mercuric iodide). Formation of a yellow coloured precipitate indicates the presence of alkaloids.

- Wagner's test includes methanolic extract treated with Wagner's reagent (iodine in potassium iodide). Formation of brown/reddish precipitate indicates the presence of alkaloids.

- Dragendroff's test includes methanolic extract treated with Dragendroff's reagent (solution of potassium bismuth iodide). Formation of red precipitate indicates the presence of alkaloids.
- Hager's test includes methanolic extract treated with Hager's reagent (saturated picric acid solution). Presence of alkaloids confirmed by the formation of yellow colored precipitate.

\section{Detection of carbohydrates}

Methanolic extract was dissolved in $5 \mathrm{ml}$ distilled water and filtered. The filtrate was used to test for the presence of carbohydrates.

- Molisch's test includes methanolic extract treated with 2 drops of alcoholic $\alpha$-naphthol solution in a test tube. Formation of the violet ring at the junction indicates the presence of carbohydrates.

- Benedict's test includes methanolic extract treated with Benedict's reagent and heated gently. Orange red precipitate indicates the presence of reducing sugars.

- Fehling's test includes methanolic extract hydrolyzed with dilute $\mathrm{HCl}$, neutralized with alkali and heated with Fehling's A and B solutions. Formation of red precipitate indicates the presence of reducing sugars.

\section{Detection of glycosides}

Methanolic extract was hydrolysed with dilute $\mathrm{HCl}$, and then subjected for glycosides test.

- Modified Borntrager's test includes methanolic extract treated with ferric chloride solution and immersed in boiling water for about 5 minutes. The mixture was cooled and extracted with equal volumes of benzene. The benzene layer was separated and treated with ammonia solution. Formation of rosepink colour indicates the presence of anthranol glycosides.

- Legal's test includes methanolic extract treated with sodium nitroprusside in pyridine and sodium hydroxide. Formation of pink to blood red colour indicates the presence of cardiac glycosides.

\section{Detection of saponins}

- Froth test includes methanolic extract diluted with distilled water to $20 \mathrm{ml}$ and this was shaken for 15 minutes. Formation of $1 \mathrm{~cm}$ layer of froth indicates the presence of saponins.

- Foam test includes $0.5 \mathrm{mg}$ of methanolic extract shaken with $2 \mathrm{ml}$ of water. If foam produced persists for ten minutes, it indicates the presence of saponins.

\section{Detection of phytosterols}

- Salkowski's test includes methanolic extract treated with chloroform and filtered. The filtrated extract was treated with few drops of concentrated sulphuric acid, shaken and allowed to stand. Appearance of golden yellow colour indicates the presence of phytosterols. 
- Libermann Burchard's test includes methanolic extract treated with chloroform and filtered. The filtrate was treated with few drops of acetic anhydride, boiled and cooled. Concentrated sulphuric acid was added. Formation of brown ring at the junction indicates the presence of phytosterols.

\section{Detection of phenols}

Ferric chloride test includes methanolic extract treated with 3-4 drops of ferric chloride solution. Formation of bluish black colour indicates the presence of phenols.

\section{Detection of tannins}

Gelatin test includes methanolic extract, $1 \%$ gelatin solution containing sodium chloride was added. Formation of white precipitate indicates the presence of tannins.

\section{Detection of flavonoids}

- Alkaline reagent test includes methanolic extract treated with few drops of sodium hydroxide solution. Formation of intense yellow colour, which becomes colourless on addition of dilute acid, indicates the presence of flavonoids.

- Lead acetate test includes methanolic extract treated with few drops of lead acetate solution. Formation of yellow colour precipitate indicates the presence of flavonoids.

\section{Detection of proteins and amino acids}

- Xanthoproteic test includes ethanolic extract treated with few drops of concentrated nitric acid. Formation of yellow colour indicates the presence of proteins.

- Ninhydrin test includes the extract, $0.25 \% \mathrm{w} / \mathrm{v}$ ninhydrin reagent was added and boiled for few minutes. Formation of blue colour indicates the presence of amino acid.

\section{Detection of diterpenes}

Copper acetate test includes extract dissolved in water and treated with 3-4 drops of copper acetate solution. Formation of emerald green colour indicates the presence of diterpenes.

\section{Procedure of GC-MS analysis of Cladophora glomerata}

GC-MS analysis of the active fractions of Cladophora glomerata seaweed was performed using GC SHIMADZU QP2010system and gas chromatograph interfaced to a mass spectrometer (GC-MS) Cladophora glomerata was extracted and concentrated by using rotary evaporator. The $1.5 \mathrm{ml}$ upper layer of extract was taken in funnel and added $100 \mu \mathrm{N}$, O-Bis (trimethylsilyl) trifluoroacetamide, trimethyl chlorosilane (BSTFA+TMCS) and $20 \mu 1$ pyridine and heated at $60^{\circ} \mathrm{c}$ for 30 minutes. To this acetonitrile was added and filtered into a conical flask. To the filtrate added $50 \mu \mathrm{BSTFA}+\mathrm{TMCS}$ and heated at $60^{\circ} \mathrm{c}$ in a water bath for 30 minutes. Filtered using $0.45 \mu$ membrane filter to a vial. ${ }^{14}$

Table 1: Qualitative phytochemical analysis of Cladophora glomerata.

\begin{tabular}{|c|c|c|c|}
\hline \multirow{2}{*}{ Phytochemicals } & & \multicolumn{2}{|l|}{ Extracts } \\
\hline & & Observations & Results \\
\hline \multirow{4}{*}{ Alkaloids } & Wagner's test & Reddish brown solution precipitate & Present \\
\hline & Mayer's test & No yellow coloured precipitate & Absent \\
\hline & Dragendroff's test & Red coloured precipitate & Present \\
\hline & Hager's test & Yellow coloured precipitate & Present \\
\hline \multirow{2}{*}{ Flavonoids } & Lead acetate test & Formation of yellow colour & Present \\
\hline & Alkaline reagent & Formation yellow colour precipitate & Present \\
\hline \multirow{2}{*}{ Phytosterols } & Salkowski's test & No golden yellow colour precipitate & Absent \\
\hline & Libermam Burchard's test & No brown ring & \\
\hline Diterpenes & Copper acetate test & Emerald green colour & Present \\
\hline \multirow{3}{*}{ Carbohydrates } & Molisch's test & Violet ring at the junction & Present \\
\hline & Benedict's test & Orange red precipitate & Present \\
\hline & Fehling's test & Red coloured precipitate & Present \\
\hline \multirow{2}{*}{ Glycosides } & Modified Borntrager's test & No formation of rose-pink colour precipitate & Absent \\
\hline & Legal's test & Pink to blood red colour precipitate & Present \\
\hline \multirow{2}{*}{ Saponins } & Froth test & Thin layer of foam & Present \\
\hline & Foam test & Foam produced persists for 10 minutes & Present \\
\hline Phenols & Ferric chloride test & No formation of bluish black colour precipitate & Absent \\
\hline Tannins & Gelatin test & No formation of white colour precipitate & Absent \\
\hline \multirow{2}{*}{ Proteins and amino acids } & Xanthoproteic test & No formation yellow colour precipitate & Absent \\
\hline & Ninhydrin test & No formation of blue colour precipitate & Absent \\
\hline
\end{tabular}


Table 2: GC-MS activity in methanolic extract of Cladophora glomerata.

\begin{tabular}{|c|c|c|c|c|}
\hline Retention time & Compound name & Molecular formula & Molecular weight & $\%$ peak area \\
\hline 6.05 & Formamide, N, N-diethyl- & $\mathrm{C}_{5} \mathrm{H}_{11} \mathrm{NO}$ & 101 & 0.77 \\
\hline 6.62 & Acetamide, n-ethyl- & $\mathrm{C}_{4} \mathrm{H}_{9} \mathrm{NO}$ & 87 & 0.51 \\
\hline 7.20 & Acetamide, N, N-diethyl- & $\mathrm{C}_{6} \mathrm{H}_{13} \mathrm{NO}$ & 115 & 2.94 \\
\hline 7.38 & Acetamide, n-ethyl- & $\mathrm{C}_{4} \mathrm{H}_{9} \mathrm{NO}$ & 87 & 2.83 \\
\hline 9.48 & 2-ethylhexyl acetate & $\mathrm{C}_{10} \mathrm{H}_{20} \mathrm{O}_{2}$ & 172 & 0.51 \\
\hline 11.06 & Benzene, 1,3-bis(1,1-dimethylethyl)- & $\mathrm{C}_{14} \mathrm{H}_{22}$ & 19 & 0.41 \\
\hline 14.54 & Phenol, 3,5-bis(1,1-dimethylethyl)- & $\mathrm{C}_{14} \mathrm{H}_{22} \mathrm{O}$ & 206 & 0.47 \\
\hline 15.48 & 1,2-Benzenedicarboxylic acid, diethyl ester & $\mathrm{C}_{12} \mathrm{H}_{14} \mathrm{O}_{4}$ & 222 & 0.33 \\
\hline 15.55 & 1-Hexadecene & $\mathrm{C}_{16} \mathrm{H}_{32}$ & 224 & 1.88 \\
\hline 16.48 & 8-Pentadecanone & $\mathrm{C}_{15} \mathrm{H}_{30} \mathrm{O}$ & 226 & 0.86 \\
\hline 16.79 & Heneicosane & $\mathrm{C}_{21} \mathrm{H}_{44}$ & 296 & 0.36 \\
\hline 17.82 & 1-Octadecene & $\mathrm{C}_{18} \mathrm{H}_{36}$ & 252 & 2.95 \\
\hline 17.89 & Heneicosane & $\mathrm{C}_{21} \mathrm{H}_{44}$ & 296 & 0.38 \\
\hline 18.54 & 1,2-Benzenedicarboxylic acid & $\mathrm{C}_{16} \mathrm{H}_{22} \mathrm{O}_{4}$ & 278 & 0.74 \\
\hline 18.66 & 8-Octadecanone & $\mathrm{C}_{18} \mathrm{H}_{36} \mathrm{O}$ & 268 & 1.91 \\
\hline 19.04 & Silane, trichlorooctadecyl- & $\mathrm{C}_{18} \mathrm{H}_{37} \mathrm{CISI}$ & 386 & 0.80 \\
\hline 19.17 & Hexadecanoic acid, methyl ester & $\mathrm{C}_{17} \mathrm{H}_{34} \mathrm{O}_{2}$ & 270 & 9.58 \\
\hline 19.47 & Dibutyl phthalate & $\mathrm{C}_{16} \mathrm{H}_{22} \mathrm{O}_{4}$ & 278 & 0.51 \\
\hline 19.52 & Dibutyl phthalate & $\mathrm{C}_{16} \mathrm{H}_{22} \mathrm{O}_{4}$ & 278 & 27.07 \\
\hline 19.86 & 1-Octadecene & $\mathrm{C}_{18} \mathrm{H}_{36}$ & 252 & 3.76 \\
\hline 19.98 & Eicosyl acetate & $\mathrm{C}_{22} \mathrm{H}_{44} \mathrm{O}_{2}$ & 340 & 1.15 \\
\hline 20.64 & 10-Nonadecanone & $\mathrm{C}_{19} \mathrm{H}_{38} \mathrm{O}$ & 282 & 0.73 \\
\hline 20.80 & $\mathrm{n}$-Nonadecanol-1 & $\mathrm{C}_{19} \mathrm{H}_{40} \mathrm{O}$ & 284 & 2.78 \\
\hline 20.87 & 9-Octadecenoic acid, methyl ester, (E)- & $\mathrm{C}_{19} \mathrm{H}_{36} \mathrm{O}_{2}$ & 296 & 0.69 \\
\hline 20.93 & 11-Octadecenoic acid, methyl ester, (Z)- & $\mathrm{C}_{19} \mathrm{H}_{36} \mathrm{O}_{2}$ & 296 & 0.54 \\
\hline 20.98 & Oxirane, hexadecyl- & $\mathrm{C}_{18} \mathrm{H}_{36} \mathrm{O}$ & 268 & 0.67 \\
\hline 21.04 & Unknown compound & No hit compound & & 0.16 \\
\hline 21.11 & Methyl stearate & $\mathrm{C}_{19} \mathrm{H}_{38} \mathrm{O}_{2}$ & 298 & 0.72 \\
\hline 21.22 & 14-Pentadecenoic acid & $\mathrm{C}_{15} \mathrm{H}_{28} \mathrm{O}_{2}$ & 240 & 0.53 \\
\hline 21.43 & Octadecanoic acid & $\mathrm{C}_{18} \mathrm{H}_{36} \mathrm{O}_{2}$ & 284 & 1.22 \\
\hline 21.68 & Tridecane, 3-methylene- & $\mathrm{C}_{14} \mathrm{H}_{28}$ & 196 & 0.41 \\
\hline 21.73 & Behenic alcohol & $\mathrm{C}_{22} \mathrm{H}_{46} \mathrm{O}$ & 326 & 2.90 \\
\hline 21.84 & Acetic acid n-octadecyl ester & $\mathrm{C}_{20} \mathrm{H}_{40} \mathrm{O}_{2}$ & 312 & 1.11 \\
\hline 22.69 & Eicosyl pentafluoropropionate & $\mathrm{C}_{23} \mathrm{H}_{41} \mathrm{~F}_{5} \mathrm{O}_{2}$ & 444 & 1.42 \\
\hline 22.81 & Unknown compound & No hit compound & & 0.42 \\
\hline 23.39 & Hexanedioic acid, bis(2-ethylhexyl) ester & $\mathrm{C}_{22} \mathrm{H}_{42} \mathrm{O}_{4}$ & 370 & 0.35 \\
\hline 23.44 & 1-Heptacosanol & $\mathrm{C}_{27} \mathrm{H}_{56} \mathrm{O}$ & 396 & 1.55 \\
\hline 24.56 & 1,2-benzenedicarboxylic acid & $\mathrm{C}_{24} \mathrm{H}_{38} \mathrm{O}_{4}$ & 390 & 8.11 \\
\hline 24.81 & Oxalic acid, cyclohexyl tetradecyl ester & $\mathrm{C}_{22} \mathrm{H}_{40} \mathrm{O}_{4}$ & 368 & 0.75 \\
\hline 25.03 & Octacosanol & $\mathrm{C}_{28} \mathrm{H}_{58} \mathrm{O}$ & 410 & 0.76 \\
\hline 31.44 & Cholesterol & $\mathrm{C}_{27} \mathrm{H}_{46} \mathrm{O}$ & 386 & 6.66 \\
\hline 33.42 & Octatriacontyl trifluoroacetate & $\mathrm{C}_{40} \mathrm{H}_{77} \mathrm{~F}_{3} \mathrm{O}_{2}$ & 646 & 6.81 \\
\hline
\end{tabular}

\section{RESULT}

\section{Identification of components}

Interpretation of mass spectrum GC-MS was done using the database of National Institute Standard and Technique (NIST08s), WILEY8 and FAME having more patterns.
The spectrum of the unknown component was compared with the spectrum of the known components stored in the NIST08s, WILEY8 and FAME library.

The name, molecular weight, molecular formula and structure of the component of the test material was as certained. 


\section{Phytochemical analysis and GC-MS analysis of Cladophora glomerata}

The phytochemical screening of methanolic extract of Cladophora glomerata showed the presence of alkaloids, flavonoids, carbohydrates, diterpenes, glycosides and saponins (Table 1). On contrary phytosterols, phenols, tannins, proteins and amino acids were absent.

\section{GC- MS interpretation}

The components present in the crude extract of Cladophora glomerata were identified by GC-MS. The various components with their retention time, molecular formula, molecular weight and percentage composition in the crude extract of the drug is shown in Table 2. Total of 42 compounds were identified in the extract. The major compounds were dibutyl phthalate (27.07\%), hexadecanoic acid, methyl ester (9.58\%), 1,2benzenedicarboxylic acid (8.11\%), Octatriacontyl trifluoroacetate $(6.81 \%)$, cholesterol $(6.66 \%)$. All other components were less than $4 \%$ and hence found to be less significant, as their bioavailability is negligible.

\section{DISCUSSION}

Phytochemical analysis refers to extraction, screening and identification of the medicinally active substances found in plants. The bioactive substances which can be derived from plants are flavonoids, alkaloids, carotenoids, tannins, antioxidants and phenolic compounds. These bioactive compounds have great medicinal values. Seaweeds contain many bioactive compounds of medicinal value with potential pharmaceutical application. The qualitative phytochemical studies were carried out on methanolic extract of Cladophora glomerate for different constituents.

Table 3: Important major compounds with their pharmacological activity of Cladophora glomerata.

\begin{tabular}{|lll|}
\hline Chemical compounds & Molecular formula & Pharmacological activity \\
\hline Dibutyl phthalate & $\mathrm{C}_{18} \mathrm{H}_{37} \mathrm{CL}$ & Anti-bacterial activity, antimetabolic activity ${ }^{23,24}$ \\
\hline Hexadecanoic acid, methyl ester & $\mathrm{C}_{16} \mathrm{H}_{32} \mathrm{O}_{2}$ & Anti-bacterial, cancer preventive, antiarthritic properties \\
\hline 1,2-Benzene dicarboxylic acid & $\mathrm{C}_{24} \mathrm{H}_{38} \mathrm{O}_{4}$ & Neurodegenerative disorders, anti-cancer activity. \\
\hline Octatriacontyl trifluoroacetate & $\mathrm{C}_{40} \mathrm{H}_{77} \mathrm{~F}_{3} \mathrm{O}_{2}$ & Insecticidal $^{26}$ \\
\hline
\end{tabular}

Cladophora glomerata showed the presence of alkaloids, flavonoids, carbohydrates, diterpenes, glycosides and saponins. Flavonoids have been proved with antitumor and antioxidant properties. ${ }^{15}$

Alkaloids were found to have antimicrobial, cytotoxic and antispasmodic properties. ${ }^{16-21}$ Terpenoids possess antiinflammatory and hypoglycaemic activities. ${ }^{22}$ In GC MS analysis, total of 42 compounds were identified in the extract. The broad range of compounds such as amines, alcohols, esters and ethers can be observed in chromatogram.

The active principles with their retention time, molecular weight and molecular formula are presented in Table 2. The major compounds are listed in Table 3.

Dibutyl phthalate is known to have anti-bacterial activity and antimetabolic activity, hexadecanoic acid, methyl ester is known to have anti-bacterial, cancer preventive and antiarthritic properties, 1,2-benzenedicarboxylic acid can be used in neuro-degenerative disorders and as anti-cancer agent, octatriacontyl trifluoroacetate an constituent found in extract can be used for insecticidal properties. ${ }^{23-26}$

According to previous studies fresh water Cladophora glomerata is a source of bioactive substances with cosmetic importance and can be used as ingredients in cosmetic preparations. ${ }^{8}$

\section{CONCLUSION}

In the present study, methanolic extract of Cladophora glomerata contains active phytochemical compounds such as alkaloids, flavonoids, diterpenes, saponins, carbohydrates and glycosides. GC-MS analysis showed 42 different compounds. The presence of bioactive substances identified in this study need to be further investigated (in vitro and in vivo) for the potential medicinal properties of the Cladophora glomerata (green alga) for their pharmacological activities for their use in various clinical conditions.

\section{ACKNOWLEDGEMENTS}

Authors would like to thank authorities of Central InterDisciplinary Research Facility, SBV University and the Central Council for Research in Siddha, Chennai, India for support during study.

Funding: No funding sources Conflict of interest: None declared

Ethical approval: The study was approved by the Institutional Ethics Committee 


\section{REFERENCES}

1. Cox, S, Abu-Ghannam N, Gupta, S. An assessment of the antioxidant and antimicrobial activity of six species of edible Irish sea weeds. Inter Food Res J. 2010;17:205-220.

2. Faulkner DJ. Marine natural products. Natural Product Rep. 2000;17(1):7-55.

3. Whankatte VR, Ambhore JS. Study of phytochemical screening and antioxidant activities of Cladophora glomerata Linn. collected from Raigad Coast of Konkan (MS) India. J Sci Nat. 2016;7:659-63.

4. Tyagi N, Bohra A. Screening of phytochemicals of fruit plant and antibacterial potential against Pseufomonas aeruginosa. Biochem Cell Arch. 2002;2:21-24.

5. Wijesekara I, Kim SK. Angiotensin-I-converting enzyme (ACE) inhibitors from marine resources: Prospects in the pharmaceutical industry. Marine Drugs. 2010;8(4):1080-93.

6. Wijesekara I, Pangestuti R, Kim SK. Biological activities and potential health benefits of sulfated polysaccharides derived from marine algae. Carb Polymers. 2011;84(1):14-21.

7. Wijesekara I, Yoon NY, Kim SK. Phlorotannins from Ecklonia cava (Phaeophyceae): biological activities and potential health benefits. Biofactors. 2010;36(6):408-14.

8. Fabrowska J, Leska B, Schroeder G. Freshwater Cladophora glomerata as a new potential cosmetic raw material. Chemik. 2015;69(8):495-7.

9. Heiba HI, Al-Easa HS, Rizk AF. Fatty acid composition of twelve algae from the coastal zones of Qatar. Plant Foods Human Nutrition. 1997;51(1):2734.

10. Elenkov I, Georgieva T, Hadjieva P, DimitrovaKonaklieva S, Popov S. Terpenoids and sterols in Cladophora vagabunda. Phytochemistry. 1995;38(2):457-9.

11. Saadatmand S, Khavarinejad R, Nejadsattari T, Soltani S. Antioxidant and antibacterial activities of Cladophora glomerata (L.) Kütz. in Caspian Sea Coast, Iran. Afr J Biotech. 2011;10(39):7684-9.

12. Tiwari P, Kumar B, Kaur M, Kaur G, Kaur H. Phytochemical screening and extraction: a review. Inter Pharmaceut Sci. 2011;1(1):98-106.

13. Mythili T, Ravindhran R. Phytochemical screening and antimicrobial activity of Sesbania sesban(L.) Merr. Asian J Pharm Clin Res. 2012;5(4):179-82.

14. Thomas ET, Aneesh TP, Thomas DG, Anandan R. GC-MS analysis of phytochemical compounds present in the rhizomes of Nervilia aragoana Gaud. Asian J Pharm Clin Res. 2013;6(3):68-74.
15. Cody V, Middleton E, Harborne JB, Baretze A. Plant flavonoids. In: Alan R, eds. Biology and Medicine II: Biochemical, Cellular and Medicinal Properties. Liss Inc. New York; 1988: 330.

16. Omulokoli E, Khan B, Chhabra SC. Antiplasmodial activity of four Kenyan medicinal plants. J Ethnopharmacol. 1997;56(2):133-7.

17. Cowan MM. Plant products as antimicrobial agents. Clin Microbiol Rev. 1999;12(4):564-82.

18. Srivastava N, Saurav K, Mohanasrinivasan V, Kannabiran K, Singh M. Antibacterial potential of macroalgae collected from the Madappam coast, India. Brit J Pharmacol Toxicol. 2010;1(2):72-6.

19. Nobori T, Miura K, Wu DJ, Lois A, Takabayashi K, Carson DA. Deletions of the cyclin-dependent kinase4 inhibitor gene in multiple human cancers. Nature. 1994;368(6473):753.

20. Stray F. The natural guide to medicinal herbs and plants. Tiger Books International: London; 1998: 1216.

21. Okwu DE, Okwu ME. Chemical composition of Spondias mombin Linn plant parts. J Sustain Agric Environ. 2004;6(2):140-7.

22. Cherian S, Augusti KT. Insulin sparing action of leucopelargonin derivative isolated from Ficus bengalensis Linn. Ind J Exp Biol. 1995;33:608-11.

23. Khatiwora E, Adsul VB, Kulkarni M, Deshpande NR, Kashalkar RV. Antibacterial activity of dibutyl phthalate: a secondary metabolite isolated from ipomoea carnea stem. J Pharm Res. 2012;5(1):150-2.

24. Roy RN, Laskar S, Sen SK. Dibutyl phthalate, the bioactive compound produced by Streptomyces albidoflavus 321.2. Microbiol Res. 2006;161(2):1216.

25. Krishnamoorthy K, Subramaniam P. Phytochemical profiling of leaf, stem, and tuber parts of Solena amplexicaulis (Lam.) Gandhi using GC-MS. Inter Scholarly Res Notices. 2014;13.

26. Ravi R, Zulkrnin H, Shaida N, Rozhan NN, Yusoff N, Raihan N, et al. Evaluation of two different solvents for Azolla pinnata extracts on chemical compositions and larvicidal activity against Aedes albopictus (Diptera: Culicidae). J Chem. 2018;7453816.

Cite this article as: Usha NS, Anand SJV, Mangaiyarkarasi. Preliminary phytochemical screening and GC-MS analysis of Cladophora glomerata: green marine algae. Int J Basic Clin Pharmacol 2019;8:732-7. 